\title{
BITY, WIRUSY, SIECI. TRZY PRZYPADKI POLSKIEJ SZTUKI NAJNOWSZEJ: LISEK/BRZEZIŃSKI/JANICKI
}

Agnieszka Jelewska

Interdyscyplinarne Centrum Badawcze Humanistyka/Sztuka/ Technologia Uniwersytet im. Adama Mickiewicza w Poznaniu

Technologie i techniki widzenia, styszenia oraz transmisji danych moga być odnalezione w najbardziej zaskakujacych miejscach. (Parikka 2010: XIX)

Wielu teoretyków nowych mediów czy filozofów nauki podkreśla, że translacja danych, język programowania i sieciowe formy komunikacji stanowią podstawowe wyznaczniki współczesnego paradygmatu kultury i sztuki cyfrowej. Tekst eksploruje tę tezę w nowych kontekstach przez połączenie trzech obszarów: nauki, sztuki i filozofii. Odwołuje się do przykładów z teorii i eksperymentów dokonanych w naukach ścisłych, działań polskich artystów z przestrzeni paradygmatu art and science oraz wybranych narzędzi i pojęć z filozofii poststrukturalistycznej.

Znaczna część tekstu omawia studia przypadków z zakresu sztuki, które w sposób bezpośredni wskazują na różne sposoby i poziomy nawiązywania relacji między artystycznym procesem twórczym i naukowym eksperymentem, między nowymi technologiami i sposobami ich nie tyle używania, ile raczej dekonstruowania i wpisywania w nowe konteksty społeczno-kulturowe. Prace Roberta B. Liska, Michała Brzezińskiego i Pawła Janickiego nazywam przypadkami (cases): są to projekty, które nie do końca podlegaja linearnemu opisowi, korzystając bowiem z nielinearnych systemów zapisu, języka matematyki czy danych genetycznych, nakierowane sa na procesualność, na zmianę i ciagłe mutacje. Jednocześnie na ich obecność na pograniczach praktyki artystycznej, teorii i nauki warto spojrzeć jak na case studies - otwierające możliwości eksplorowania wątków podejmowanych zarówno przez artystów, jak i naukowców, lecz także humanistów czy współczesną myśl filozoficzna. Wskazane w tekście wątki mogą więc posłużyć do dalszego rozwijania idei, konceptów, języków i doświadczeń poruszanych przez artystów i wynikających z ich prac. 


\section{/// Maszyny mutacyjne}

Seria wykładów, jakie miały miejsce w 1943 roku w Trinity College w Dublinie, ma znaczące miejsce wśród wielu zdarzeń, odkryć naukowych, które wpłynęły na przekraczanie granic między dyscyplinami nauk ścisłych i otworzyły nowe możliwości rozwijania badań nad życiem na poziomie kodu danych. Wykłady te prowadził znany już wówczas fizyk Erwin Schrödinger. Fenomen tych wystąień, pod znaczącym tytułem Cazym jest syccie?, polegał na tym, że badacz zasugerował połączenie badań z zakresu fizyki kwantowej, teorii matematycznych i biologii, stawiając mocną tezę, że życie na prymarnym poziomie złożoności zasadza się na mutacji struktur pozbawionych przewidywalnych powieleń, bardzo podobnych do występujących w przyrodzie aperiodycznych kryształów, których forma wewnętrzna jest opisywalna na podstawie chaotycznych reakcji czasteczkowych. Jednocześnie Schrödinger próbował nazwać (jeszcze przed odkryciem DNA) skomplikowaną dynamikę szyfru komórek organicznych. Rozważając teorię dziedziczenia, w połączeniu z koncepcjami matematycznymi i reakcjami zachodzącymi w świecie kwantów, uznał, że opisanie, czyli zrozumienie mechanizmów powstawania i rozwoju życia na poziomie komórkowym jest zadaniem transdyscyplinarnym i bezsprzecznie powiązanym z procesami mutacji danych. Istnieja, jak twierdził, dwa sposoby rozbudowywania „małych cząsteczek” w większe formy:

Jednym jest powielanie tej samej struktury [...]. Tak się dzieje w rosnących kryształach. Z chwila, gdy ustalona zostanie budowa komórki elementarnej, dalszy rozrost kryształu nie ma teoretycznie granic. Drugim sposobem jest rozbudowa agregatu nieoparta na nudnej, okresowej powtarzalności. Tak się dzieje w przypadku coraz bardziej skomplikowanych cząsteczek substancji organicznych, w których każdy atom czy grupa atomów odgrywa indywidualną rolę (inaczej niż w przypadku struktury periodycznej). W takim przypadku możemy mówić o aperiodycznym ciele stałym lub krysztale i sformułować hipotezę, iż gen, a może i całe włókno chromosomowe - jest aperiodycznym ciałem stałym. (1998: 75-76)

Schrödinger, analizując prace Hugo Marie de Vriesa ${ }^{1}$, wskazywał, że mutacje genów na poziomie życia organicznego zachodzą skokowo i często „spontanicznie” pod wpływem rozmaitych czynników, jak „przypadkowa fluktuacja energii drgań” (1998: 78). Aperiodyczna natura kryształu,

\footnotetext{
${ }^{1}$ Znany holenderski botanik i genetyk, który już pod koniec XIX wieku rozwinął badania nad teorią mutacji i dziedziczności.
} 
będącego dla niego źródłem czy też wręcz matrycą życia organicznego, pozwala zakodować praktycznie nieskończoną liczbę możliwości nawet przy stosunkowo małej liczbie atomów. Materia żywa, przekonywał Schrödinger, wymyka się więc dążeniu do stanu równowagi - definiowanego przez niego jako bezład prowadzący do śmierci układu. Gwarancją jego przeżycia jest to, że każdy żywy organizm pobiera $z$ otoczenia tak zwaną ujemną entropię ${ }^{2}$. Miał to być też dowód na to, że życie jest raczej powiązane z destabilizacją i ruchami chaotycznymi niż ruchami porządkującymi i schematycznymi. Schrödinger wygłaszał swoje wykłady w czasach rozwoju maszyn liczących, systemów kodowania i dekodowania informacji (teoria Shannona-Weavera ${ }^{3}$ ), układów sprzężonych Norberta Wienera, jednak jego śmiała wówczas koncepcja, wskazująca na niewystarczalność stabilnych praw fizyki klasycznej w świecie mniejszych cząstek, zapowiadała połączenie doświadczeń wielu dziedzin i nowe odkrycia naukowe ${ }^{4}$, przyczyniające się do rudymentarnych zmian w rozumieniu budowy świata i, co ważne, niestabilności struktur, które konstruują nasze życie.

Austriacki teoretyk wykonał także jeden z pierwszych kroków prowadzących do pokazania, że maszyna mutacyjna (dla niego wzorem takiej maszyny były aperiodyczne kryształy i procesy skokowych zmian zachodzące w ich wnętrzach) może być w wielu aspektach nieprzewidywalna. Późniejsze badania na temat mutacji danych doprowadziły do odkrycia DNA, następnie przez przekształcenia na poziomie nauk ścisłych również nauki humanistyczne i kulturoznawcze sięgnęły po model mutacji i rozpoczął się trwający już wiele lat dyskurs warunkujący badania kultury jako formy mutacji danych czy jako zestawu przekształcanych algorytmicznych procedur. W tym procesie bardzo silnie uczestniczyła filozofia poststrukturalistyczna. Maszyna mutacyjna stała się ważnym elementem rozumienia mechanizmów translacji w filozofii Gilles'a Deleuze'a i Félixa Guattariego: maszynowe phylum (machinic phylum), o którym pisali filozofowie, stało się

\footnotetext{
${ }^{2}$ Krytykowany za tę koncepcję Schrödinger wskazywał później, że entropia ujemna nie jest entropia wzięta ze znakiem minus, a raczej pojęciem bliskim energii swobodnej. Energia swobodna to ta część energii pobranej w pokarmie lub zmagazynowanej w organizmie, którą organizm może przetworzyć na pracę nieobjętościowa.

${ }^{3}$ Chodzi o znana pracę The Mathematical Theory of Communication - opublikowana w 1949 roku - zawierająca podstawy teorii informacji przedstawione przez Claude'a Shannona i esej omawiający tę teorię autorstwa Warrena Weavera. Praca ta jest jedna z kluczowych dla zrozumienia roli i funkcji matematyki w koncepcjach przesyłu danych, kodowania i dekodowania informacji. Warto też pamiętać, że dla Shannona znaczenie informacji było stosunkowo nieistotne, ważny był sposób zapisu danych. Pisał, że informacja jest ściśle powiązana z niepewnością i jest entropią, czyli miarą chaosu w termodynamice. Podobnie myślał Schrödinger, używając tego terminu (zob. Shannon 1993: 173).

${ }^{4}$ Aperiodyczne kryształy Schrödingera stały się ważną inspiracją między innymi dla biologów Jamesa D. Watsona i Francisa Cricka, którzy niezależnie od siebie odkryli strukturę DNA.
} 
maszyną mutacyjną, która może łączyć ze sobą, dzielić i kopiować różne poziomy rzeczywistości, jak też dziedziny wiedzy i nauki. Za pomoca kodu, przekształcania danych, procesów informacyjnych mogą więc być dokonywane zmiany zarówno na poziomie molekularnym, jak i społeczno-politycznym. W tym szerokim spektrum rozumienia maszyny mutacyjnej mechanizmy rzeczywistości moga być rozpatrywane jako translacja danych, polegająca na uruchamianiu oprogramowania, pisaniu algorytmów i protokołów, które odpowiedzialne są za kolejne ich przekształcenia.

\section{$/ / /$ Art and science}

Współczesna sztuka, szczególnie ta, która sięga po rozwiązania technologiczne i posługuje się narzędziami cyfrowymi, eksploruje również teorie naukowe. Eksperymentuje i często krytycznie odnosi się do nowych odkryć badawczych. Staje się w ten sposób formą metajęzyka: sytuuje się wewnątrz dyskursu związanego z szerokim spektrum zagadnień dotyczących ludzkiej i postludzkiej kondycji, sytuacji usieciowionej podmiotowości, form mutacji i przemian zachodzących na poziomie życia organicznego, a w konsekwencji wskazuje na ich konsekwencje w kulturze i społeczeństwie. Działania artystyczne często są bliskie rozważaniom teoretycznym opartym na naukowych konceptach, ponieważ skupiaja się na procesie, na badaniu zjawisk i ich możliwych implikacji społecznych. Od algorytmistów ${ }^{5}$ i interaktywnych badań nad relacją między człowiekiem i komputerowym interfejsem ${ }^{6}$ czy też komunikacją transgatunkową aż po genetyczne przekształcenia $^{7}$ (zob. Wilson 2010) sztuka ta operuje na najbardziej prymarnych poziomach kodu dającego współcześnie możliwości translacji rozmaitych danych na wielorakie systemy i formy prezentacji. Paradygmat łączący sztukę i naukę (art and science) ma swoje źródła w poszukiwaniach artystów już w latach sześćdziesiątych i siedemdziesiątych XX wieku, kiedy pojawiły się nowe narzędzia technologiczne, ale także rozwijały się badania nad możliwością łączenia takich dziedzin jak informatyka, matematyka z jednej strony, a biologia, chemia czy neurologia z drugiej.

\footnotetext{
${ }^{5}$ Algoryści (algorytmiści) to artyści posługujący się w swoich pracach, najczęściej graficznych, algorytmami. W 1995 roku stworzyli grupę o tej właśnie nazwie; byli wśród nich między innymi Jean-Pierre Hérbert, Roman Verostko.

${ }^{6} \mathrm{Już}$ pierwsze projekty z lat siedemdziesiątych Myrona Kruegera, jednego z pionierów sztuki interaktywnej, zakładały eksplorowanie różnych możliwych form komunikacji człowiek-komputer.

${ }^{7}$ Klasyczne już dziś prace Eduardo Kaca, Victorii Vesny i Jamesa Gizmewskiego, australijskiej grupy Symbiotica, interaktywne prace Christy Sommerer i Laurenta Mignonneau są jedynie wprowadzeniem w obręb sztuki, w której pojawia się dziś bardzo wielu artystów zajmujących się tymi zagadnieniami na różnych poziomach, przy wykorzystaniu wielu narzędzi twórczych.
} 
Jedną z ważniejszych prac teoretyczno-historycznych śledzących ten paradygmat jest klasyczna już dziś książka Stephena Wilsona Information Arts z 2002 roku. Autor opisuje w niej współczesnych artystów, którzy podjęli wysiłek przekroczenia granic między sztuką i nauką w poszukiwaniu nowych form wyrazu, ale też definiowania takich zagadnień, jak proces twórczy, eksperyment, etyka badawcza, rozwój narzędzi. Wilson stawia tezę, że eksperyment artystyczny miewa często podobną strukturę do eksperymentu naukowego, w obu wypadkach ważne sa poszukiwania nowych rozwiązań, proces, eksplorowanie granic i ich przekraczanie. Jednocześnie autor formułuje istotne pytania wskazujące na skomplikowaną sieć relacji łączących naukę i działania artystyczne:

Jaki rodzaj relacji może zaistnieć pomiędzy sztuką̧ badaniami naukowymi i technologicznymi innowacjami? W jaki sposób sztuka i nauka moga wzajemnie się inspirować? W jaki sposób artyści moga prowadzić techno-naukowe badania? [...] W jaki sposób badania naukowe moga rozwijać artystyczne poszukiwania? W jaki sposób historycy sztuki i teoretycy kultury rozumieją interakcję pomiędzy kulturą i nauką? Jak tworzy się dyskurs naukowy? Co motywuje plany badawcze? Znajdujemy się w interesującym momencie historii, w którym czasami trudno jest wprowadzać rozróżnienia pomiędzy badaniami techno-naukowymi a sztuką - jest to znakiem tego, że na naszych oczach tworzą się szersze, zintegrowane perspektywy poznawcze sztuki i nauki. [...] Nasza kultura desperacko potrzebuje szerokiego zaangażowania w tworzenie definicji procedur badań, $\mathrm{w}$ aktualne procesy doświadczalne [...]. Artyści moga mieć znaczący wpływ na ten dyskurs poprzez rozwijanie nowych modeli pracy. (Wilson2003: 3)

W paradygmacie art and science umieścić można wielu twórców drugiej połowy XX wieku i nowego stulecia, zarówno tych, którzy zajmuja się bio- i nanoartem, sztuką software'u, projektowaniem graficznym i algorytmicznym, jak i wieloma innymi formami. Lączenie i przekraczanie granic między nauką i sztuką staje się dziś ważnym polem eksploracji, jednak jest to możliwe w dużej mierze dlatego, że język tworzenia i eksperymentowania w obu sferach jest związany z możliwością translacji danych i na tym poziomie kreowania nowej jakości, wartości czy artefaktu. Jednak zainteresowanie operacjami, procedurami i najmniejszymi cząstkami informacji, mające miejsce zarówno w obrębie nauk ścisłych (biologicznych czy chemicznych), jak i sztuki, wiąże się również z nowymi możliwościami wykorzystania narzędzi cyfrowych do odkrywania i mutowania różnych warstw i poziomów życia w techno-kulturowych strukturach rzeczywistości. 
„To, co nazywamy rzeczywistością - pisał John Archibald Wheeler - wynika w ostatecznej analizie z zadawania binarnych [zero-jedynkowych] pytań”. I dodawał: „Wszystko, co fizyczne, ma źródło informacyjno-teoretyczne, i na tym polega partycypujący wszechświat" (Wheeler 1994: 290-298).

Programowanie i rozwijanie procedur algorytmicznych na każdym poziomie wiedzy, jak twierdzi Wolfgang Ernst $^{8}$, wpływa na zmiany, jakie zachodzą w strukturach kulturowych, które stają się coraz bliższe językowi programowania. W takim ujęciu wszechświat przypomina gigantyczny komputer - kosmiczną maszynę do przetwarzania informacji. Ernst na określenie tej sytuacji używa terminu „kulturowa inżynieria” i definiuje kulturę jako język prymarnie zdeterminowany przez matematykę, kody, szyfry, dane i formuły, które istnieja w sieciowym obiegu. Dopiero zejście na ten poziom odsłania to, co według niego stanowi o epistemologicznym wymiarze współczesnej zmediatyzowanej kultury. W tym układzie sztuka stanowi często sferę eksploracji różnych wątków, fragmentów, eksperymentów czy też narzędzi, które determinuja procesy poznawcze i doświadczenie w digitalnej rzeczywistości. Z perspektywy determinizmu kulturowego tego typu analizę zaproponował Lev Manovich. W swojej, opublikowanej w internecie książce Software Takes Command, zwraca on uwagę na nowy uniwersalizm współczesności:

Wyszukiwarki sieciowe, systemy rekomendacji, aplikacje mapujące, narzędzia blogowe, narzędzia aukcyjne, natychmiastowe programy komunikacyjne i oczywiście platformy, które umożliwiają innym pisanie nowego oprogramowania - Facebook, Windows, Unix, Android - znajduja się w centrum globalnej ekonomii, kultury, życia społecznego, równocześnie wywierając coraz większy wpływ na politykę. To „oprogramowanie kulturowe” - kulturowe w tym sensie, że jest bezpośrednio używane przez setki milionów ludzi oraz zawiera w sobie ,atomy” kultury (media, informacje) jak również ludzkie interakcje z mediami i informacjami są tylko widoczną cząstką znacznie większego wszechświata software'u. To oprogramowanie kontroluje trajektorię lotu inteligentnego pocisku w kierunku wyznaczonego celu w czasie wojny, korygując na bieżąco wszystkie parametry.

\footnotetext{
${ }^{8}$ Wolfgang Ernst to jeden z ważniejszych obecnie niemieckich medioznawców, zajmujących się ideą archiwów, jak też historycyzmem w erze cyfrowych mediów. W swoich książkach, między innymi: M.edium F.oucault (2000), Das Rumoren der Arcbive (2002), Das Gesetz, des Gedächtnisses (2007), rozwija tezy postawione przez Friedricha Kittlera i analizuje nowe możliwości kształtowania narracji na temat medialnych struktur rzeczywistości. W licznych wykładach postuluje nawet tezę, iż media studies powinny powrócić na łono nauk ścisłych, gdyż to właśnie język matematyki generuje rzeczywistość medialna, a tym samym kulturową i polityczną.
} 
Oprogramowanie organizuje pracę hurtowni i linie produkcyjne Amazonu, Gapa, Della i wielu innych firm, umożliwiając gromadzenie i wysyłkę przedmiotów materialnych na cały świat oraz redukując czas tego procesu do niezbędnego minimum. Oprogramowanie pozwala sklepom i supermarketom automatycznie uzupełniać towary na półkach, jak również automatycznie podejmować decyzje, które towary powinny zostać przecenione, na jak długo i w którym miejscu przestrzeni sklepu powinny być eksponowane. Software jest również oczywiście tym, co organizuje Internet, kieruje ruchem mailowym, dostarcza strony WWW z serwerów, steruje ruchem w sieci, przypisuje adresy IP i renderuje strony WWW w przeglądarce. Szkoła i szpital, baza wojskowa i laboratorium naukowe, lotnisko i centrum miasta wszystkie społeczne, ekonomiczne i kulturowe systemy współczesnego społeczeństwa są organizowane dzięki software'owi. Oprogramowanie komputerowe jest niewidocznym klejem, który to wszystko spaja. Mimo że różne systemy współczesnego społeczeństwa mówia w różnych językach i mają różne cele, to jednak wszystkie posługują się syntaksą software'u [...]. (2008: 3-4)

Manovich używa terminu „oprogramowanie kulturowe” jako formy kształtowania języka opisu działań kulturowych i społecznych. Wycięcie z dyskursu nauk humanistycznych, społecznych, politycznych poziomu programowania i sposobów dystrybucji wiedzy w wielu wypadkach skazuje badacza na opis zaledwie powierzchni rzeczy, ich otoczki, a więc outputu procesów dokonujących się poprzez algorytmy, które zostały wymyślone do programowania i projektowania sieci komunikacji. Algorytmy stają się podstawą współczesnego rozumienia świata, a sieć jest kategoria, która oplata coraz szersze pola znaczeniowe Funkcjonujemy w świecie komunikacji transkodowanej, w sieci różnych form materii ożywionej i nieożywionej, w rzeczywistości biologiczno-informatycznej.

Radykalne tezy - dotyczące badań i rozumienia współczesnej funkcji mediów - które odnajdujemy między innymi w pismach wspomnianego już Wolfganga Ernsta, mówiące o tym, że mechanizmy algorytmiczne w dużej mierze zaprogramowane są tak, aby sterować wiedza, pozycjonować ją według obliczeń matematycznych - mają swoje oczywiste odzwierciedlenie również w sztuce. Operacje, przekształcenia i mutacje, dokonywane w ramach działalności artystycznej, opierają się na procedurach transpozycji algorytmicznych, nie zaś linearnych ciagach semantycznych. „Translacja - pisze Jussi Parrika - nie jest operacja lingwistyczna [...], ale transpozycją, a nawet czymś więcej, aktywną operacją na poziomach 
niedyskursywnej produkcji medialnej" (2010: XIII). Dlatego też takie działania artystyczne wymagaja jednocześnie nowego oprzyrządowania analitycznego służącego ustaleniu zachodzących w niej przemian nie tyle estetycznych, ile przede wszystkim percepcyjnych i epistemologicznych w sytuacji niekończącego się transkodowania danych pomiędzy obiegami sieci o różnej przynależności topologicznej. Multimedia - według Ernsta - nie istnieja już bez czasowych algorytmicznych procesów, przez które następuje proces przekodowywania praktycznie wszystkiego: dźwięku, obrazu, fragmentów DNA i tak dalej.

\section{/// Przypadek \#1: biomolekularne transkodowanie}

Jednym z polskich artystów, który w swoich projektach, performansach i działaniach podejmuje wątki rzeczywistości sterowanej algorytmicznie, jest Robert B. Lisek (logik i artysta). W projekcie SPECTRUM, zrealizowanym dla warszawskiej galerii Leto w 2008 roku, podją temat bioterroryzmu ${ }^{9}$. Projekt miał formę scenariusza ataku bioterrorystycznego na Warszawę. Istota przedsięwzięcia było wskazanie na relacje pomiędzy technologia biomolekularna, transkodowaniem, replikacja, samoreplikacja i możliwościami transmisji kodu w sieci. W Laboratorium Biologii Molekularnej Uniwersytetu Wrocławskiego Lisek, wykorzystując reakcję łańcuchowa polimerazy, wyhodował nowy, nienazwany szczep bakterii E. coli, który bardzo szybko rozprzestrzeniał się w wodzie. Na podstawie planu miasta twórca opracował najszybszą metodę zainfekowania całej Warszawy. W jego artystycznym zamyśle bakterie miały być transportowane między innymi za pomoca sieci wodociagowej.

Mapa pozwala zrozumieć - twierdzi artysta - w jaki sposób patogeny (w tym wypadku moja bakteria E. coli) rozprzestrzeniają się i tworzą złożone biologiczne i komunikacyjne sieci. Graficzna prezentacja uzmysławia, jak niebezpieczne moga być nowe szczepy bakterii i jak szybko mogą się one rozprzestrzeniać w takim mieście jak Warszawa. (Lisek 2008)

Artysta napisał także program komputerowy, który przetwarzał dane wyjściowe z procesu polimerazy w dźwięki i światło. W kolejnej fazie eksperymentu Lisek wszczepił bakterie w struktury roślin, wykorzystując białka zielonej fluorescencji, i otrzymał fluoroscencyjne rośliny-bakterie. Wydaje się, że w projekcie Liska multiplikacji ulegają struktury różnych sieci, ujawniając ukryte relacje wszystkich układów komunikacyjnych.

${ }^{9}$ Szczegółowa dokumentacja projektu: http://lisek.art.pl/gespenst.html (dostęp: 07.05.2012) 


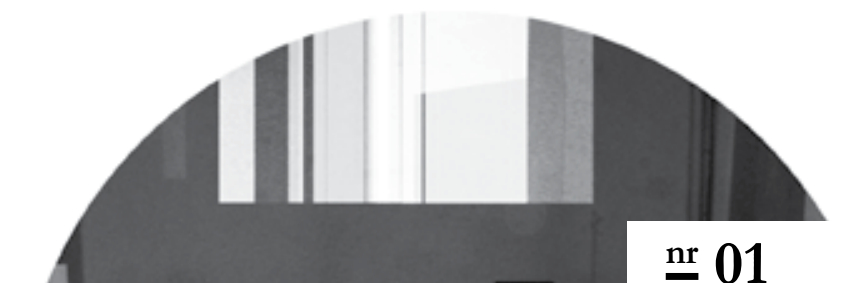

Robert B. Lisek, Spectrum,

Galeria LETO Warszawa 2008.

(fot. RBL.)

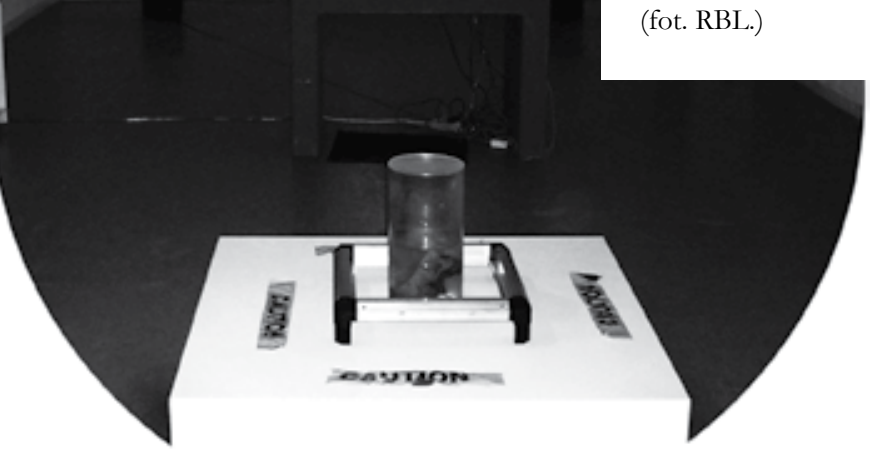

nx 02

Robert B. Lisek, Spectrum,

Galeria LETO Warszawa 2008.

(fot. RBL.) 
Za pomoca „zainfekowanej komunikacji” łączy się układy rzeczywiste i wirtualne (potencjalne), co wskazuje na ich niebezpieczna analogiczną strukturę.

Lisek niejako uruchamia maszynę mutacyjna. Maszynowe phylum, o którym pisali Deleuze i Guattari, to zestaw samoorganizujących się procesów, w których grupy wcześniej niepołączonych elementów nagle docierają do punktu krytycznego, gdzie zaczynaja ze sobą „współpracować”, łączyć się i mutować w większe całości, tak jak nienazwany szczep bakterii wyhodowany przez Liska. Pojęcie phylum w definicji filozofów znosi granice między tym, co organiczne i nieorganiczne, stając się jednym z możliwych pojęć opisujących niebezpieczny moment, w którym wyhodowane w laboratoriach formy, wpuszczone w obręb sieci, zaczną łączyć się ze sobą w sposób niekontrolowany, tworząc nieznane wcześniej bioobiekty, mutanty. W ramach definicji phylum fenomen samoorganizacji zachodzi wtedy, kiedy następuje bifurkacja (rozdzielenie) elementów w określonej fazie przestrzeni, kiedy pojawia się nowy atraktor albo kiedy system atraktorów wewnętrznie się mutuje w odpowiedzi na własne ruchy. Dla filozofów maszynowe phylum to szeroko definiowane odmiany maszyn abstrakcyjnych, które napędzaja proces stawania się. Jednak z perspektywy współczesnych badań genetycznych może ono być również rozumiane jako dynamika algorytmów sterujących w ramach systemu sieciowego różnymi poziomami mutacji i przepływu danych (zob. Deleuze, Guattari 1987). Lisek w swoim projekcie wyraźnie wskazuje na to, że integracja oddzielonych wcześniej sfer współczesności sprawia, że obwody neuronalne, teleinformatyczne, somatyczne, limfatyczne, a nawet wodociagi czy drogi staja się poziomami tej samej sieci - połączonej i współzależnej. W tym układzie nie ma działań bez konsekwencji, a podstawowa kategoria jest konwergencja. Sieć, potencjalne miejsce wolnej komunikacji, jest także podatna na sterowanie. Doświadczenia, afekty, wyniki badań - wszystko, co nas opisuje - może być transkodowane na bity informacji wymienianych przez miliony nawiązywanych połączeń (zob. także Jelewska 2012: 185-196). Robert B. Lisek w swoich projektach wskazuje wyraźnie, że pewne elementy digitalne i somatyczne moga być ze sobą sprzęgnięte. Podstawą regulująca rzeczywistość są algorytmy, które współdefiniują i współkonstruują komunikację. Również w ramach masowej komunikacji przesyłanie informacji staje się jednostką manipulacji życia. I nie chodzi tu tylko o relacje społeczne i polityczne, które ulegaja zmianie, ale równocześnie o poziom biologiczny, o cykl obiegu danych zawartych w naszych genach. 
W jednym z ostatnich projektów CAPITAL (2011) Lisek skonstruował obiekt porównujący jego własny kod DNA (uzyskany ze śliny) z kodem wybranych wirusów (Lloviu, Polio, Marburg, Ebola, HIV). Instalacja składa się z: systemu dekodującego DNA, autorskiego oprogramowania, które dokonuje transformacji i syntezy kodu genetycznego artysty z wirusami. Fragmenty kodów wirusów mutują się z DNA Liska, tworząc wciąż poszerzającą się kombinację. Proces ten jest także wizualizowany - na projekcji widzowie mogą obserwować modyfikujące się struktury genów opisanych za pomoca sekwencji liter. Integralną częścia projektu jest także trójwymiarowa makieta prezentująca przekrój budynku siedziby Muzeum Sztuki Współczesnej we Wrocławiu, gdzie instalacja była prezentowana po raz pierwszy. Makieta, będąca architektonicznym zapisem danych, odzwierciedla labiryntową konstrukcję budynku - nazistowskiego wielopoziomowego bunkra z czasów drugiej wojny światowej ${ }^{10}$. Istotą CAPITAL jest zastosowany przez Liska rozszerzający się model danych, w którym wszystko jest albo jednostka, albo funkcja. Umożliwia to niekończący się rozrost tego systemu i anektowanie nieobecnych w nim jeszcze wirusów i bioobiektów.

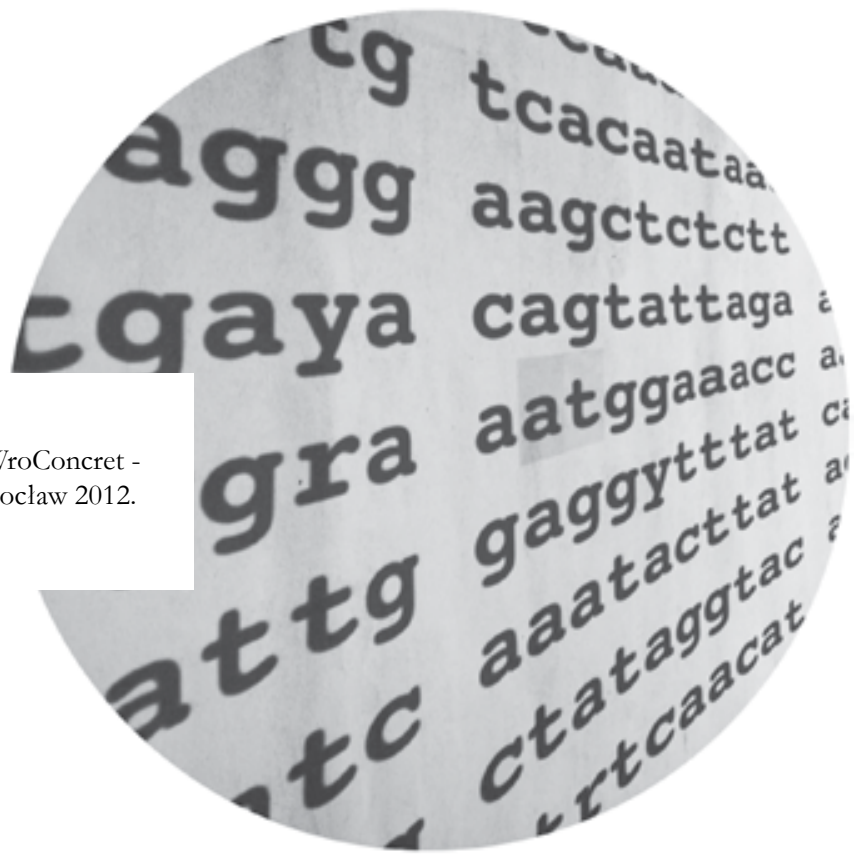

\footnotetext{
${ }^{10}$ Szczegółowy opis wraz z abstraktem wykorzystanych badań naukowych dostępny jest na stronie internetowej: http://lisek.art.pl/CAPITAL.html (dostęp: 17.08.2012)
} 
Artystę interesuje w tym projekcie rzeczywisty mechanizm phylum, naukowa analiza sposobów, za pomocą których kody organizmów staja się dostępne i wymienialne. Obszar ten jest głównie zagarnięty przez duże koncerny farmaceutyczne, które opatentowują nowe formuły kodów i czerpią z tego zyski. Działanie artysty jest zatem projekcją sytuacji, w której stworzone formy kodu, udostępniane powszechnie i za darmo, będa mogły destabilizować i decentralizować obecny system. W założeniu Liska wybrane kody, które w przyszłości będą rezultatem kombinacji kodów wirusów i ludzkiego DNA, mogą zostać zsyntetyzowane; w ten sposób powstaną nowe formy nieludzkiego życia. Działanie artysty, w tym wymiarze, jest próbą zdefiniowania kryteriów możliwości rozwoju postludzkich obiektów czy jednostek przez przebadanie kwalifikatorów oraz granic tego, co ludzkie. Formy postludzkiego kodu, które próbował wygenerować, sa realizacja jego teoretycznych badań nad idea singularity, czyli efektu osobliwości, momentu, w którym - jak twierdzi między innymi Raymond Kurzweil - rozwój technologii sprawi, że będziemy mogli przedłużać formy istnienia w wymiarze nieskończonym (zob. Kurzweil 2006). Lisek jednak dostrzega w koncepcji singularity zagrożenie dla gatunku ludzkiego. Twierdzi, że komunikacyjne, sieciowe przyspieszenie wymiany danych doprowadzi do nieznanych nam jeszcze form synergii między nauką i technologia, tym samym bardzo szybko zaczną rozwijać się samogenerujące systemy superinteligentne, mogące w przyszłości zagrozić człowiekowi. Jego projekt CAPITAL eksploruje więc problematykę związaną z postępem w badaniach nad sztuczną inteligencją, nanotechnologią i bioinżynieria.

\section{/// Przypadek \#2: FAKE ART}

Michał Brzeziński to drugi polski teoretyk-artysta często sięgający do problematyki transformacji. W swoim cyklu FAKE ART (2011) wykorzystuje strategie naukowego poznania i form prezentacji laboratoryjnych wyników badań ${ }^{11}$. Jednak prawdziwa natura tych prac nie do końca jest jasna. Często mamy tu do czynienia z mistyfikacją i jednoczesnym kreowaniem współczesnego naukowego mitu wiedzy. Brzeziński sytuuje współczesną działalność artystyczną blisko badań naukowych, stawia pytania o odpowiedzialność i etykę niektórych projektów z zakresu biotechnologii i inżynierii genetycznej. Dotyka problemów tożsamości współczesnego ciała wynikających z technicznych możliwości reprodukcji komórek i genotypów,

\footnotetext{
${ }^{11}$ Szczegółowa dokumentacja projektu na stronie: http://www.brzezinski.zdnet.pl/michal-brzezinski/ artist/artistic-events/fake-art-2. Brzeziński wcześniej zajmował się również ontologią obrazu wideo, jako artysta-teoretyk jest autorem między innymi terminu wideo-tożsamość (zob. Brzeziński 2011a).
} 
a także z tworzącej się dzięki poznaniu naukowemu nowej relacji pomiędzy gatunkami na poziomie ich podobieństwa komórkowego. Tworząc sugestywne konteksty dla swoich wystaw, które ekspozycyjnie często przybierają formę prezentacji laboratoryjnych, przedstawiających na przykład różne urządzenia pomiarowe, sugeruje on naukową legitymizację swojej twórczości. W tym ujęciu to, co naukowe, staje się w powszechnym odczuciu prawdziwe i konsekwentne, zapewnia społeczny kredyt zaufania. Sztuka Brzezińskiego, choć jest „fake”, to stara się zaistnieć wewnątrz naukowego dyskursu i aktywnie analizować jego wpływ na rzeczywistość. $\mathrm{Na}$ poziomie konceptualnym Brzeziński wnika do ważnych poziomów dzisiejszego poznania świata, do sfery cząsteczkowej, mikrobów i wirusów, będących często symbolicznym polem kulturowego wykluczenia - formą współcześnie rozumianego abiektu świata stechnologizowanej kultury chcącej zachować stabilność, równomierny wzrost i przede wszystkim sterylność. W tej rzeczywistości wirusy stają się elementem zewnętrznym, wykluczonym poza ciało, organizmem obcym, niosąc ze sobą zagrożenie mutacja - destabilizacją struktury organizmu.

\section{ne 03}

Michał Brzeziński, Bios i Zoe, BWA Nowy Sącz 2011

(fot. RBL.)

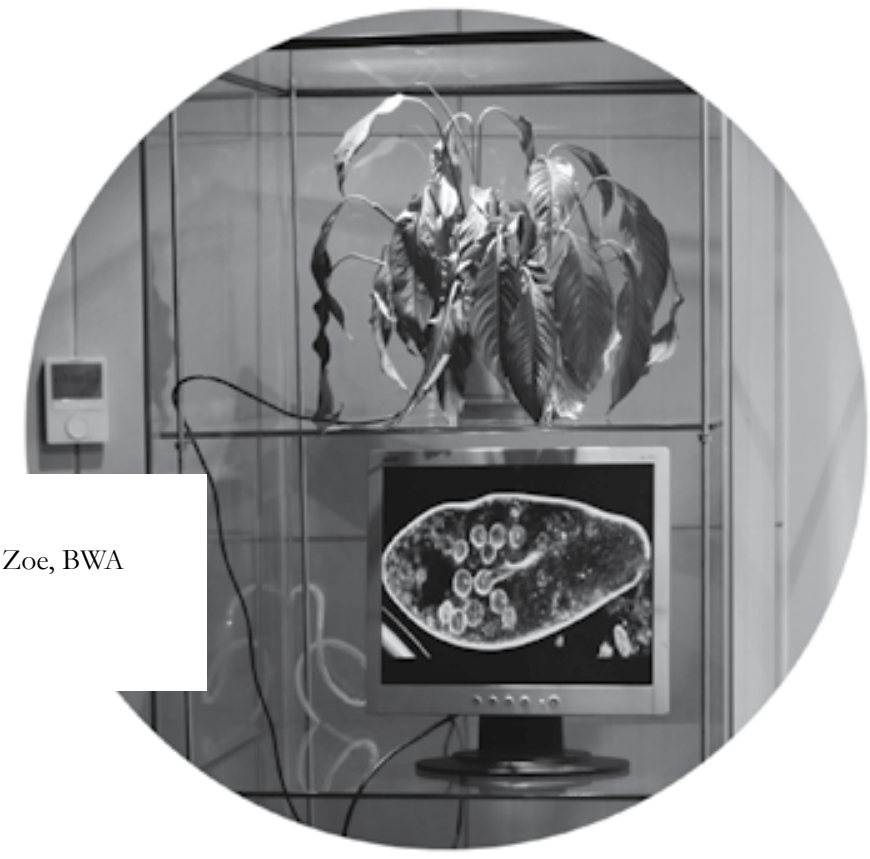


Praca zatytułowana BIOS i ZOE (Netfootage Performing Flower) z 2011 roku jest obiektem realizującym naukową teorię symbiozy rośliny i komputera. Gardenia ogrodowa podpięta do gniazda usb za pomoca sensora galwanicznego uzyskuje możliwość prezentowania, za pomoca dostępnych jej algorytmów, swoich stanów afektywnych. Praca, będąca oczywiście kolejnym artystycznym „fakiem”, w kontekście najnowszych badań, realizowanych między innymi przez polskiego naukowca Stanisława Karpińskiego nad inteligencją, systemami komunikacyjnymi i komputacją roślin ${ }^{12}$, nabiera dużo bardziej poważnego charakteru. Sam artysta wskazuje także na kontekst społeczny swoich działań:

Giorgio Agamben pisze o wykluczonym z kultury Zoe jako o nagim życiu, które można uśmiercić, nie narażając się na moralne potępienie. Agamben odnosi się oczywiście do shoah jako kontekstu wykluczenia życia poza BIOS, czyli chroniona prawnie i mentalnie uprawniona formę życia, do ZOE. Nazywanie Żydów „,robactwem” jest dokładnie odzwierciedleniem tego mechanizmu. Co stanie się jednak, jeśli postanowimy zbadać obszar świadomości robaków, co jeśli okaże się, że rozumiejąc ich emocje, zaczniemy im współczuć. Co jeśli zrozumiemy ofiarę składana przez jedne formy życia innym w trakcie produkcji żywności? W jaki sposób możemy to uczynić? Technologia wydaje się już o krok od dekodowania reakcji organizmów żywych poprzez analizę ich pola elektromagnetycznego. (Brzeziński 2011b)

Brzeziński, powołując się na tekst Agambena The Open. Man and Animal, wskazuje na podobne kwestie, o których pisał filozof - na konieczność zrezygnowania $z$ antropocentrycznych form komunikacji. Agamben dawał do zrozumienia, że stan zwierzęcości jest performatywny, tak samo jak stan bycia człowiekiem, a siła tej sytuacji tkwi w nieokreślonym i często nieoznaczonym przechodzeniu pomiędzy tymi stanami. Agambenowi nie chodziło o kształtowanie hybryd, ale o poszukiwanie przestrzeni antyhybrydowej, jeszcze niespełnionej, niezaprojektowanej, gdzie „nagie życie” może na nowo zaczać się artykułować (zob. Agamben 2004). W sytuacji poszukiwania miejsc do nowej artykulacji tego, co ludzkie i roślinne, ale

\footnotetext{
${ }^{12}$ Zespół badawczy pod kierownictwem prof. Stanisława Karpińskiego (Laboratorium Fizjomiki i Modelowania Biotechnologicznego Roślin Szkoły Głównej Gospodarstwa Wiejskiego) realizuje projekt naukowy, którego celem jest „dogłębne zrozumienie roślinnych komórkowych i molekularnych mechanizmów, które przetwarzają informację kwantową, generowaną w obrębie fotosystemu II i I, na sygnały elektrofizjologiczne, redoks i hormonalne" (http://lfmbr.sggw.pl/?q=node/1). W projekcie badane są złożone sieci komunikacyjne i komputacyjne roślin oraz ich możliwości aktywnego reagowania na czynniki stresogenne.
} 
też wirusowe czy bakteryjne, sytuują się projekty z cyklu FAKE. Dość radykalnym przekroczeniem tych granic jest projekt Salami - FLESH OUT OF MY FLESH ${ }^{13}$ z 2011 roku. Przywołując naukowy artykuł z pisma „Tissue Engineering”, omawiający technologię produkcji tkanek organicznych w laboratoryjnych warunkach pozaustrojowych, Brzeziński zapowiada rozpoczęcie według tej procedury hodowli tkanki, która będzie pochodzić z jego ciała. Stworzona w ten sposób tkanka mięśniowa ma posłużyć do produkcji salami. Autokanibalizm czy też po prostu kolejny sposób wykorzystania mechanizmu namnażania się komórek? FLESH OUT OF MY FLESH mocno dyskutuje z oddzielaniem i ochroną ludzkiej cielesności wobec tego, co w kulturze zewnętrzne, przewrotnie postulując traktowanie komórek ludzkich jako materiału do produkcji pożywienia na takich samych zasadach, jak to ma miejsce w wypadku komórek zwierzęcych czy roślinnych.

Eksplorując te wątki - krytycznie zarówno wobec kultury masowej, jak i nauki - Brzeziński wypowiada się na temat mikroprocesów łączących w jeden łańcuch różne poziomy życia. Wyolbrzymiając, a może nawet przywracając wykluczone i niedoświetlone obszary współczesnego doświadczenia, wskazuje na moźliwości modelowania afektywnej komunikacji. Na swojej stronie internetowej artysta opisał koncept „instrumentu” muzycznego, opartego na sprzężeniu zwrotnym między wokalistką a ruchem bakterii obserwowanych pod mikroskopem.

Ruch bakterii będzie przekształcany na dźwięk - opisuje system działania Brzeziński - dodatkowo naniesiona warstwa wokalna zostanie dodana do tego dźwięku i przekształcona w pole elektromagnetyczne, które z kolei będzie działało na bakterię. Bakteria sama będzie swoimi ruchami stymulowała zmianę, natężenie i intensywność napięcia elektrycznego wytwarzanego przez elektrody. Oczywistym efektem będzie też elektroliza jako efekt oddziaływania dźwięku, powodowana intensywnością napięcia. Elektroliza doprowadza do zmian jonizacji wody, uwalniania się tlenu i wodoru z wody i wysychania naczynia, w którym znajdują się bakterie. Wysychanie wody jest więc procesem wyczerpywania się zasobów życiowych, a kurczenie się zasobów jest skorelowane $z$ intensywnościa życia, a ta intensywność stymulowana jest przez własna aktywność. Na tę aktywność nakłada się oczywiście słowo ludzkie. Ta praca przekształca więc ludzkie słowo, śpiew, melodię

${ }^{13}$ Szczegółowa dokumentacja projektu na stronie: http://www.brzezinski.zdnet.pl/michal-brzezinski/inspirations/salami-flesh-out-of-my-flesh 
w energię korzystająca z zasobów bakterii. Dla człowieka natomiast stymulacja jest ruch bakterii, który dzięki komputerowi tworzy dźwięk, a zasobem ludzkim jest czas, który został przewidziany na ten eksperyment artystyczny. (Brzeziński 2012)

Brzezińskiego interesują formy komunikacji pozawerbalnej, racjonalnej i emocjonalnej: schodząc na poziom afektu, chce odkryć nowe możliwości trangresywnych międzygatunkowych struktur relacyjnych.

Jussi Parikka w książce, na którą również powołuje się Brzeziński, Insect Art: An Archaeology of Animals and Technology, pisze, że insekty i wirusy - jako zdolne do afektywnej komunikacji, niesamowitych doznań, nieprzewidywalnych możliwości i zachowań, istniejące poza ramami modeli, które tradycyjnie służą do ich opisu - stają się dziś modelem dla medialnych form komunikacji. Insekty są mediami (jako formy komunikacji), a media insektami. Tak jak zwierzęta są w ciągłej relacji z otoczeniem,

tak środowisko medialne, w którym żyjemy, jest skonstruowane z naszych etologicznych ciał będących $\mathrm{w}$ interakcji $\mathrm{z}$ ciałami technologicznymi, politycznymi i ekonomicznymi. Albo inaczej rzecz ujmując: nie tyle mamy media, ile jesteśmy mediami. (Parikka 2010: XXVII)

Analizując prace Brzezińskiego w kontekście najnowszych technologii i odkryć naukowych, trudno „złapać” wyraźną granicę pomiędzy fikcja i prawda. Właściwie można powiedzieć, że stają się one rozbudowanym elementem perfomatywnej sieci skojarzeń, danych, faktów, teorii i koncepcji. Brzeziński wciąż testuje powiązania i samogenerujące możliwości tych układów.

\section{/// Przypadek \#3: DE/STABILIZACJE SIECI}

Z jednej strony usieciowienie może budzić niepokój - zmediatyzowaną kategorię freudowskiej niesamowitości $-\mathrm{z}$ drugiej zaś wydaje się, że może prowadzić do nowego typu globalnej ekologii: biologicznoinformatycznej globalnej odpowiedzialności przyznającej potencjalnie wszystkim użytkownikom możliwość swobodnego poruszania się po sieci. Świadomość usieciowienia i znajomość mechanizmów zarządzania, które nie są tożsame z naszym językiem i sposobem prowadzenia narracji, pozwalają nawiązywać konsekwentne połączenia poza z góry zdefiniowanymi, nastawionymi na sterowanie globalnymi systemami. W tej rzeczywistości nie ma niczego, co jednoznacznie określa funkcjonowanie całego systemu, a ostateczny jego kształt zależy wyłącznie od ekologii użytkowania sieci. 


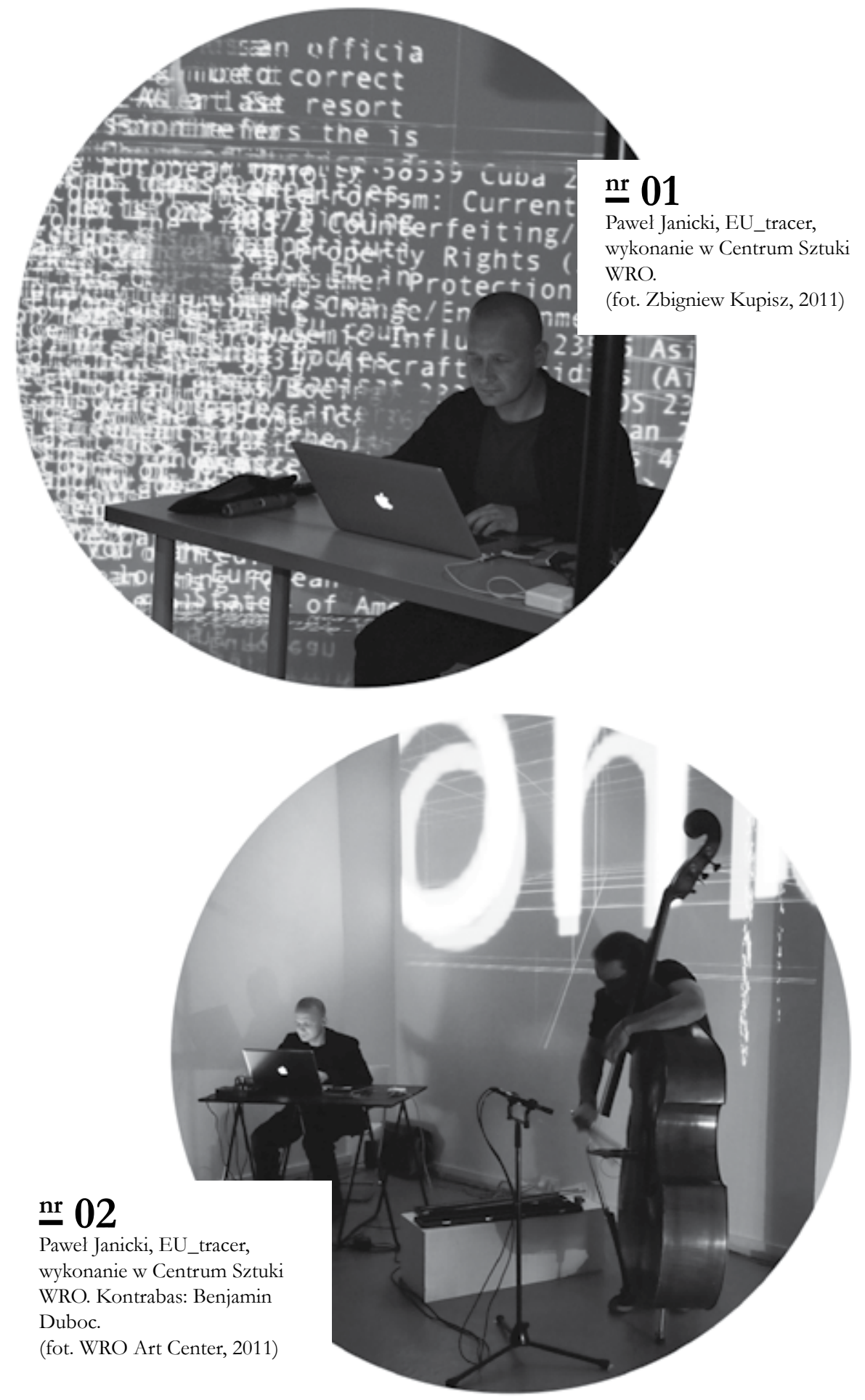


powiązań sieciowych, jest Paweł Janicki. W swoim projekcie EU TRACER (2011 rok) ${ }^{14}$ wykorzystał techniki analizowania i skanowania danych pochodzących z sieci, które następnie generowały struktury muzyczne i były umieszczane w formie graficznej w trójwymiarowej przestrzeni projekcji. Akcji towarzyszył muzyk, który improwizował do działań Janickiego. Performans odbywał się w różnych miastach europejskich (Brukseli, Paryżu, Mińsku, Wrocławiu, Lwowie). Wykonując to działanie w Brukseli, Janicki skanował dane pochodzące z serwerów Parlamentu Europejskiego i różnych europejskich instytucji, udostępniając w ten sposób publicznie elementy poufnych informacji. Z kolei w czasie wystapienia na Białorusi ruch internetowy przekierowywał wciąż artystę na witrynę „, Lukaszenko ostatni dyktator", które to hasło wyświetlało się na ekranie pośród innych filtrowanych $\mathrm{z}$ sieci informacji. W innym projekcie PING MELODY (realizowany od 2003 roku) Janicki w ramach działania na żywo także eksplorował możliwości komunikacyjne i interaktywne sieci ${ }^{15}$. Do projektu zapraszał muzyków - dźwięk ich instrumentu czy wokal najpierw były zamieniane w pakiet danych, który wysyłano w przestrzeń sieci, a później powracał zniekształcony przez opóźnienia i błędy, które wystapiły w trakcie transmisji. Sferę wizualna performansu tworzyły udostępniane przez artystę informacje o transmisji i pojawiających się błędach. W PING MELODY część wykorzystywanego kodu software’u została skopiowana przez niego z oprogramowania stworzonego przez naukowców DARPA ${ }^{16}$. Janicki zrewitalizował militarny system stworzony przez amerykańską agencję, dzięki przystosowaniu go do działalności artystycznej uczynił z niego część układu nowoczesnego instrumentu muzycznego. Jak sam pisał:

Jestem zainteresowany pewną wyjątkową cechą globalnego środowiska komunikacyjnego, będącą sprawą kluczową dla struktur decyzyjnych (rządów, administracji, kadry kierowniczej itd.). Mianowicie: charakterystycznym dla wielu technokratycznych kultur przejściem od systemu decyzyjnego skierowanego przeciwko jednostkom lub grupom, zaburzającego wspólnotowy status quo, do systemu kolektywnego, legalnego, automatycznego lub algorytmicznego. [...] Czynniki odpowiedzialne za sprawowanie kontroli w nowym systemie mogą być lokowane przez instytucje nadzorujące wewnątrz grup. Zatem akty represjonowania

\footnotetext{
${ }^{14}$ Szczegółowa dokumentacja projektu na stronie: http://paweljanicki.jp/eutracer/ (dostęp: 27.07. 2012).

${ }^{15}$ Szczegółowa dokumentacja projektu na stronie: http://paweljanicki.jp/pingmelody_main_en.html (dostęp: 27.07.2012).

${ }^{16}$ Amerykańska organizacja Defense Advanced Research Projects Agency (DARPA).
} 
skierowane formalnie w destabilizujące czynniki, mogą w rzeczywistości być formami strategii obronnych zaczerpniętymi ze struktur decyzyjnych [...]. Algorytmiczne, automatyczne procedury utrzymują neutralny status, ich użycie jest rodzajem autokamuflażu ukrywającego prawdziwe, szczególnie wyrachowane motywy zachodzących procesów. (2003)

Janicki, przez twórcze i indywidualne rozwijanie narzędzi programowania, konstruuje otwarte systemy przepływu danych, krytycznie odnoszące się do form odgórnego sterowania siecią, wskazuje na możliwe miejsca przepięć i błędów zachodzących w samym procesie transkodowania, który może stać się początkiem nowego systemu komunikacyjnego.

Sieci - pisał Castells - są strukturami [...] zdolnymi do rozprzestrzeniania się bez ograniczeń [...] Oparta na sieci struktura społeczna jest wysoce dynamicznym, otwartym systemem [...] Mimo to morfologia sieci jest także źródłem radykalnej reorganizacji stosunków władzy. Lączące sieci przekaźniki (np. przepływy finansowe, przejmujące kontrolę nad medialnymi imperiami, które wpływaja na procesy polityczne) są uprzywilejowanymi instrumentami władzy. A zatem ci, którzy kontrolują przełączniki, są posiadaczami władzy. (2011: 492)

Stosując strategię ujawniania danych i struktur, które je organizuja, Janicki zwraca uwagę na konwergencję tego, co społeczne, i tego, co technologiczne, pokazując, iż proces ten jest „podstawowym źródłem w kształtowaniu, prowadzeniu i zwodzeniu społeczeństw" (tamże: 493).

Jedna $z$ technik wykorzystywanych przez artystę jest live coding. Jest to strategia polegająca na tworzeniu kodu software'u na żywo. W czasie występu przed publicznością performer tworzy najczęściej kod generujący struktury dźwiękowe i wizualne. W tym wypadku kod definiuje całokształt tej sytuacji. Nie tylko strukturę i ontologię dzieła, lecz także kontakt i relację z publicznością. Innymi słowy interaktywność takiego zdarzenia jest kodowana na wielu poziomach, kształtuje formę przekazu, ale także rodzaje odbioru; przekracza znaczenia strukturalne i bezpośrednio determinuje charakter sytuacji. Staje się elementem zbiorowej tożsamości, często nie tylko przez metamodel podkreślający sieciowy charakter współczesnej podmiotowości, lecz także głównie przez aktywne śledzenie informacji umieszczonych w internecie, do których nie mają dostępu jego zwykli użytkownicy. 
Janicki jest także twórcą interaktywnych interfejsów i projektantem nowych typów doświadczeń w obrębie human-computer-interaction, rozwijającym doświadczenia mediów stanowiących dynamiczne struktury relacji technosomatycznych. Jego poszukiwania w przestrzeni mediów interaktywnych stały się powodem powstania takich prac, jak choćby: MAPPING CHOPIN (2010) ${ }^{17}$, w czasie której widzowie za pomocą swojego ruchu mogli wpływać na tempo i dynamikę odgrywanych utworów Chopina, czy OCEANUS (2011) ${ }^{18}$, będący próbą stworzenia interaktywnej nielinearnej narracji (praca miała formę interaktywnego stołu umożliwiającego dowolne operowanie znajdującymi się na nim wirtualnymi obiektami).

Strategie i obszary, które obiera i eksploruje Janicki - między innymi wizualizacja informacji, live coding, projektowanie interakcji i nowych typów doświadczeń medialnych - wydają się kluczowe dla najnowszej sztuki. Przekraczając uschematyzowane formy komunikacji, stają się początkiem łańcucha przemian zmieniającego myślenie o zapośredniczającej funkcji mediów. W projektach Janickiego poziomy krytyczne, takie jak wydobywanie ukrytych danych z sieci, sa bardzo często komplementarne wobec nowych typów manipulacji i eksploracji narracji medialnej. Wskazując również na społecznotwórczą funkcję software’u, o której pisał Manovich, Janicki bada możliwości sieci jako niekończących się dekonstrukcji i konstrukcji kulturowych.

\section{/// Podsumowanie}

Siegfried Zielinski w książce Archeologia mediów. O głębokim czasie technicznie zapośredniczonego stuchania $i$ widzenia wskazuje, że technologia nie jest ludzka, jest raczej głęboko nieludzka. Najlepsze technologiczne osiagnięcia zostały stworzone w opozycji do tego, co w danym momencie historii było powszechnie określane jako ludzkie (Zielinski 2010). W takim pojęciu media nie są jedynie przedłużeniami człowieka, ale raczej to on staje się częścią wielopoziomowych procesów, czasem uruchamia niektóre z nich, które dalej w ramach samoreplikacji mogą kształtować osobne struktury, a nawet nieznane formy życia. Lisek tworzy algorytmiczną maszynę mutacyjną, która potencjalnie może zniszczyć jego samego; u Brzezińskiego eksperymenty z komputacją człowiek-wirus, człowiek-roślina stają się niejednoznaczne etycznie, budzą społeczny niepokój; przepięcia i kopiowanie

\footnotetext{
${ }^{17}$ Szczegółowa dokumentacja projektu na stronie: http://paweljanicki.jp/mappingchopin_en.html (dostęp: 27.07.2012).

${ }^{18}$ Szczegółowa dokumentacja projektu na stronie: http://paweljanicki.jp/oceanus_en.html (dostęp: 27.07.2012).
} 
fragmentów sieci, dokonywane przez Janickiego, mogą spowodować przerwy w dopływie danych, moga je zupełnie przekształcić i zniszczyć wiele połączeń. Deleuze i Guattari dobrze wiedzieli, że technologia dostarczająca narzędzi mutacyjnych, translacyjnych wyznacza koniec myślenia o ciele i organizmie jako o zamkniętych, ograniczonych modelach. Trzeba więc zacząć przyglądać się temu, jak nasze usieciowione organizmy wciąż artykułują się wraz z tym wszystkim, co tradycyjnie było postrzegane jako zewnętrzne wobec tego, co ludzkie.

Nie wiemy nic na temat naszego ciała - pisali - oprócz tego, że może działać, czyli jakie są jego afekty, a więc jak potrafi bądź nie potrafi połączyć się z afektami innych ciał, czy czyni to po to, by zniszczyć te ciała, czy zostać przez nie zniszczonym, czy w celu dokonania wymiany działań i emocji, czy też połączenia się z nimi w silniejszy organizm. (Deleuze, Guattari 1987: 257)

Destabilizujące procesy odsłaniaja w pewnej mierze performatywną i niejednokrotnie niestabilną strukturę życia na jego najbardziej podstawowym poziomie. Schrödinger pisał o tworzeniu się życia z aperiodycznych kryształów, niestabilnych form mutacyjnych, wydaje się, że współczesna sztuka, badając nowe formy relacji i procedury ich łączenia, transponuje je w obręb społecznego doświadczenia, czyni je bardziej wyrazistymi, możliwymi do doznania, bezpośrednimi, poza rygorami laboratoriów, odsłaniając ich programowalne mechanizmy.

„Życie wzięło się z bitu” to słynne zdanie Johna Archibalda Wheelera, ostatniego współpracownika Einsteina i Bohra, który w pracy At Home in Universe, po kilkudziesięciu latach badań nad komunikacją komórkowa, pisał, że bit stał się elementarną cząstką: nie tylko mikroskopijną, lecz i abstrakcyjna - binarną cyfra, przerzutnikiem, zero-jedynka. Informacja, według niego, ożywia wszystko - każdą cząsteczkę, każde pole siłowe, nawet nieskończoność czasoprzestrzeni. Jednak konsekwencje tego faktu moga być bardzo różne. I tu właśnie otwiera się całe pole do działań artystycznych eksplorujących różne konsekwencje współczesnej bioinżynierii i programowania, jak też współczesnych humanistów, teoretyków mediów, socjologów, kulturoznawców badających i dokonujących namysłu nad maszynami mutacyjnymi, które uruchamiane są w laboratoriach, ale przez sieci komunikacyjne są podłączone do obiegów społecznych, politycznych, etycznych itd. O ile w badaniach i sztuce anglosaskiej, niemieckiej, azjatyckiej problemy te stanowia od wielu lat istotna przestrzeń eksploracji ${ }^{19}$,

\footnotetext{
${ }^{19}$ Zob. http://userwww.sfsu.edu/infoarts/links/wilson.artlinks2.bio.html
} 
o tyle w Polsce są one wciąż raczej aktami marginalnymi. Jednakże coraz wyraźniejsza i bardziej odczuwalna niestabilność tych obiegów, a także procesy samoreplikacji różnych nowych, pojawiających się w niej bioobiektów stanowią ważne i pilne wyzwanie dla gatunku ludzkiego. Istnieje więc ciągła potrzeba powracania i redefiniowania tych skomplikowanych współczesnych zjawisk transmutacji i usieciowienia również przez strategie, jakimi posługuje się sztuka.

Bibliografia:

/// Agamben G. 2003. The Open: Man and Animal, tłum. K. Attell, Stanford University Press, California.

/// Brzeziński M. 2011a. Michał Brzeziński: FAKE ART, katalog wystawy, BWA, Nowy Sącz.

/// Brzeziński M. 2011b. Zoe, Bios... IT = Interfejs Transgatunkowy, http://www.brzezinski.zdnet.pl/michal-brzezinski/education-practice/ discussions-and-criticism/it-interfejs-transgatunkowy; dostęp: 06.06.2012.

/// Brzeziński M. 2012. Afekt: Komunikacja transgatunkowa, çyli biosztuka z perspektywy egzotyki. http://www.brzezinski.zdnet.pl/michal-brzezinski/ education-practice/discussions-and-criticism/kominikacjatransgatunkowa-czyli-biosztuka-z-perspektywy-egzoetyki; dostęp: 06.06.2012.

/// Castells M. 2011. Społeczeństwo sieci, tłum. M. Marody, Wydawnictwo Naukowe PWN, Warszawa.

/// Deleuze G., Guattari F. 1987. A Thousand Plateaus, Capitalism and Schizofrenia, tłum. B. Massumi, University of Minnesota Press, Minneapolis. /// Janicki P. 2003. Ping Melody: ideological undercurrent, http://paweljanicki. jp/pingmelody_ideologicalundercurrent_en.html; dostęp: 27.07.2012.

/// Jelewska A. 2012. Sensorium. Eseje o sztuce $i$ technologii, Wydawnictwo Naukowe UAM, Poznań.

/// Kurzweil R. 2006. The Singularity is Near: When Humans Transcend Biology, Penguin Books, London-New York.

/// Lisek R.B. 2008. Spectrum. http://lisek.art.pl/gespenst.html; dostęp: 07.08.2012. 
/// Loewestein W.R. 1999. The Touchstone of Life: Molecular Information, Cell Communication, and the Foundation of Life, Oxford University Press, New York-Oxford.

/// Manovich L. 2008. Software Takes Command. http://lab.softwarestudies. com/2008/11/softbook.html; dostęp: 05.01.2012.

/// Parikka J. 2010. Insect Media: An Archaeology of Animals and Technology, University of Minnesota Press, Minneapolis.

/// Shannon C. 1993. Collected Papers, IEEE Press, New York.

/// Shrödinger E. 1998. Caym jest àycie oraz Umyst $i$ materia. Szkice autobiograficzne, tłum. S. Amsterdamski, Prószyński i Ska, Warszawa.

/// Simondon G. 2011. On the Mode of Existence of Technical Objects, thum. N. Mellamphy, D. Mellamphy, „Deleuze Studies” 2011, vol. 5.

/// Wheeler J.A. 1994. At Home in the Universe, American Institute of Physics, New York.

/// Wilson S. 2003. Information Arts: Intersections of Art, Science, and Technology, The MIT Press, Cambridge.

/// Wilson S. 2010. Art + Science Now, Thames and Hudson, New York.

/// Zielinski S. 2010. Archeologia mediów. O głebokim czasie technicznie zapośredniczonego stuchania $i$ widzenia, tłum. K. Krzemieniowa, Oficyna Naukowa, Warszawa.

Netografia:

http://brzezinski.zdnet.pl

http://lfmbr.sggw.pl

http:/ /lisek.art.pl

http://paweljanicki.jp

http://userwww.sfsu.edu/infoarts/links/wilson.artlinks2.bio.html 


\section{/// Abstrakt}

Artykuł omawia trzy przypadki (case study) najnowszej polskiej sztuki medialnej (Robert B. Lisek, Michał Brzeziński, Paweł Janicki) w kontekście przemian kulturowo-społecznych związanych z rozwijaniem się systemów społeczeństwa sieci, jak też nauki, w tym teorii informacji, fizyki kwantowej, biologii i filozofii. Tekst wskazuje na sztukę, która ma funkcję krytyczną i destabilizującą zastane schematy komunikacyjne, naukowe i kulturowe. W tej nowejpraktyce artystycznej dochodzi bowiem do silnego sprzężenia pomiędzy działalnością twórczą oraz teoriami naukowymi i nowymi narzędziami technologicznymi.

Słowa kluczowe:

sztuka i nauka, najnowsza polska sztuka medialna, teorie mediów, społeczeństwo sieci

\section{/// Abstract}

The article discusses three cases study from new Polish media art field (Robert B. Lisek, Michał Brzeziński, Paweł Janicki) in the context of sociocultural changes connected with development of both network society systems and science including information theory, quantum physics, biology and philosophy. Text points out the art projects that have critical aim and destabilize common communicational, scientific and cultural schema. In this new artistic practice there is a strong feedback between creativity and scientific theories as well as new technological devices.

Keywords:

art and science, new Polish media art, media theory, network society 